\title{
Deepwater Spawning of Fall Chinook Salmon (Oncorhynchus tshawytscha) Spawning near Ives and Pierce Island of the Columbia River
}

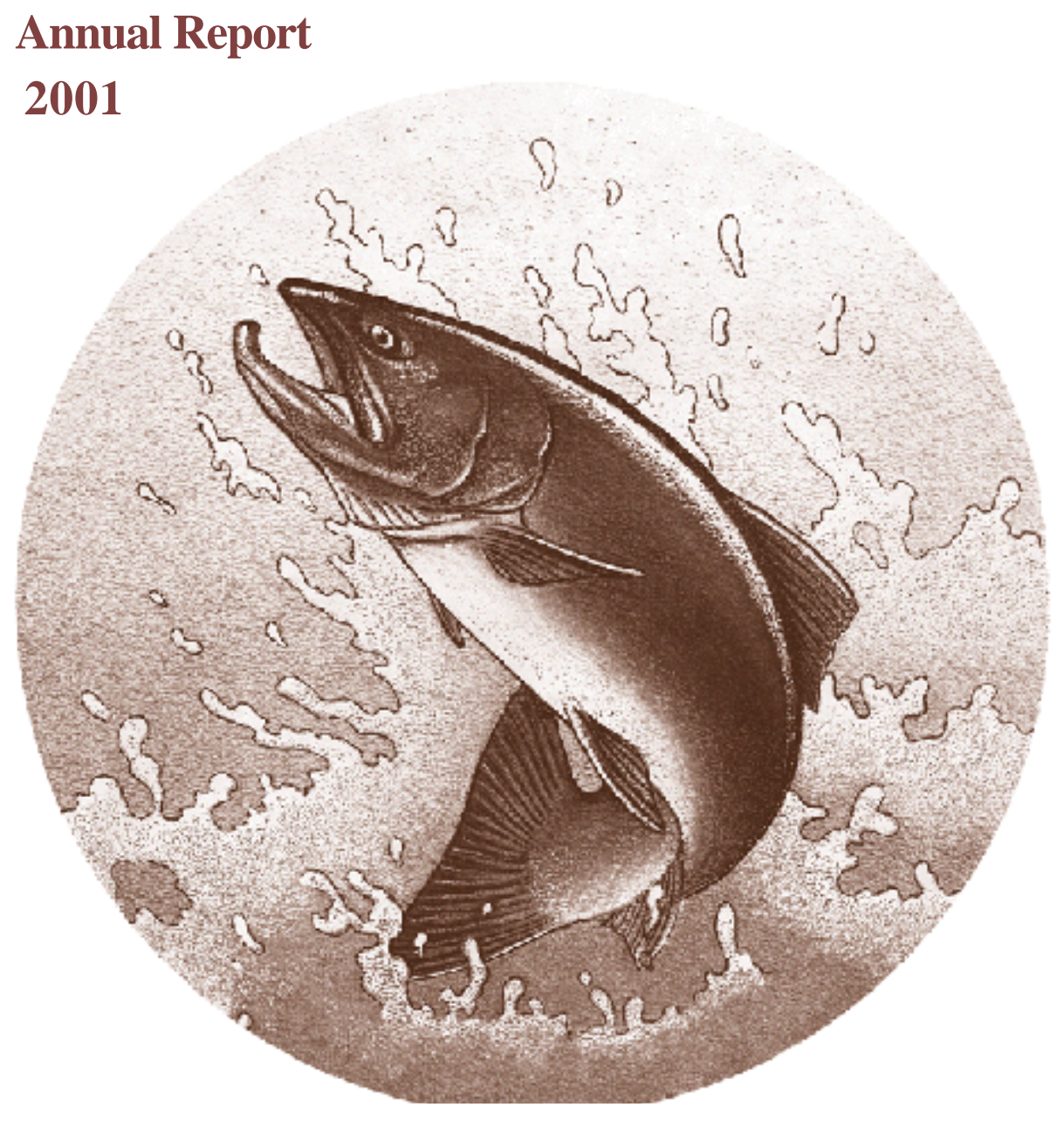

DOE/BP-00000652-10

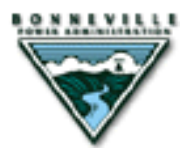

October 2002 
This Document should be cited as follows:

Mueller, Robert, "Deepwater Spawning of Fall Chinook Salmon (Oncorhynchus

tshawytscha) Spawning near Ives and Pierce Island of the Columbia River", Project No.

1999-00304, 27 electronic pages, (BPA Report DOE/BP-00000652-10)

\author{
Bonneville Power Administration \\ P.O. Box 3621 \\ Portland, Oregon 97208
}

This report was funded by the Bonneville Power Administration (BPA), U.S. Department of Energy, as part of BPA's program to protect, mitigate, and enhance fish and wildlife affected by the development and operation of hydroelectric facilities on the Columbia River and its tributaries. The views in this report are the author's and do not necessarily represent the views of BPA. 


\title{
Deepwater Spawning of Fall Chinook Salmon (Oncorhynchus tshawytscha) Spawning near Ives and Pierce Island of the Columbia River, 2001
}

\author{
Robert P. Mueller \\ Pacific Northwest National Laboratory ${ }^{1}$ \\ Richland, Washington 99352
}

October 2002

Submitted to Bonneville Power Administration

Portland, Oregon

\footnotetext{
${ }^{1}$ Pacific Northwest National Laboratory is operated for the U.S. Department of Energy by the Battelle Memorial Institute under contract DE-AC06-76RLO 1830.
} 


\section{Summary}

Pacific Northwest National Laboratory initiated studies to identify potential fall chinook salmon (Oncorhynchus tshawytscha) spawning habitat and assess the extent of spawning in deep water $(>1 \mathrm{~m})$ downstream of Bonneville Dam in the fall of 1999. This report provides results from 2001, the third year of our effort. The main objective of this study was to find deepwater spawning locations of fall chinook salmon in the main Columbia River channel, collect additional data on physical habitat parameters at spawning sites, and provide estimates of adult spawners in the area. The secondary objective was to map any chum salmon redds located in the deeper sections near Hamilton Slough.

River flows during the spawning surveys in 2001 were lower than in 1999 and 2000. Peak spawning activity, based on redd counts and live fish seen near redds, was on or near November 9, 2001. The location of the spawning area was similar to that of 1999 and 2000. One difference was the majority of redds were found in deeper water $(>1.5 \mathrm{~m})$ and closer to the shoreline adjacent to Pierce Island. Because of the low river flows during the fall of 2001, only a handful of redds were found using the boat-deployed video system within Hamilton Slough. No chum salmon $(O$. keta) redds were found in areas surveyed during 2000. (Note: surveys were limited to deeper sections of Hamilton Slough and near the main river channel.) An estimated 717 fall chinook salmon redds at water depths exceeding $1.5 \mathrm{~m}(\sim 125 \mathrm{kcfs})$ were documented in 2001 . These estimates are expanded from the number of redds found within a predefined survey area. Fall chinook salmon redds were found at water depths from $1.5-4.6 \mathrm{~m}$ and were located in a general area of $\sim 4.9$ ha. Fall chinook salmon redds were constructed in gravels ranging from $3.2-13.4 \mathrm{~cm}$ in diameter and water velocities of $0.29-0.70 \mathrm{~m} / \mathrm{s}$. 


\section{Acknowledgements}

The author thanks Scott Titzler, Corey Duberstein, and Jessica Carter for their assistance in conducting the surveys and in analysis of the videotapes. Dennis Dauble and David Geist reviewed earlier drafts of this report. 


\section{Contents}

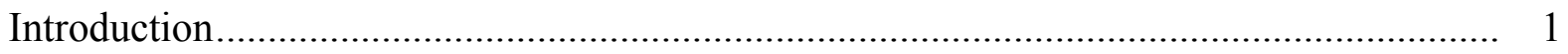

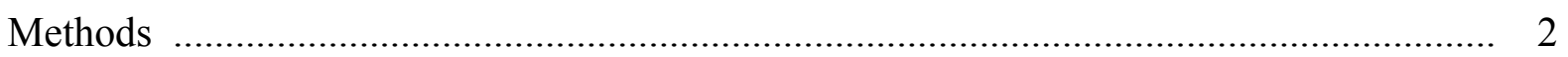

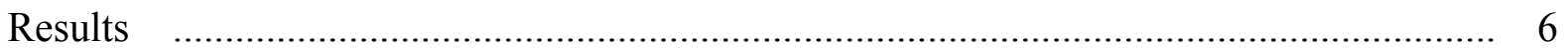

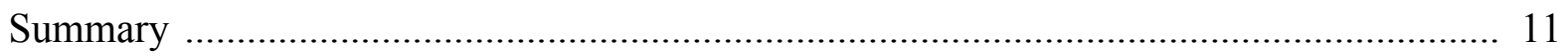

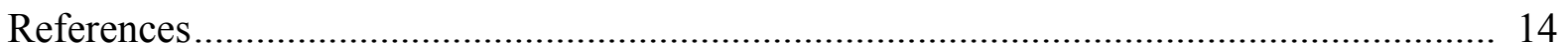

Appendix A - PNNL Redd Coordinates ............................................................................... A.1

Appendix B - Maps of Spawning Areas ............................................................................. B.1

\section{Figures}

1 Location of primary search zones in relation to Ives and Pierce Islands .................... 3

2 Location of fall chinook salmon redds in the mainstem of the Columbia River below Bonneville Dam 2001...................................................................................... 7

3 Distribution of fall chinook salmon redds $(n=92)$ relative to water depth found during the November and December surveys ................................................... 8

4 Comparison of water velocities of fall chinook salmon redds relative to water depth for 2000 and 2001

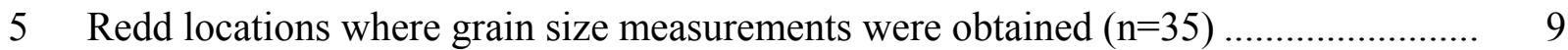

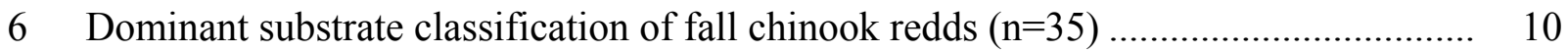

7 Location of fall chinook salmon redds in the mainstem of the Columbia River below

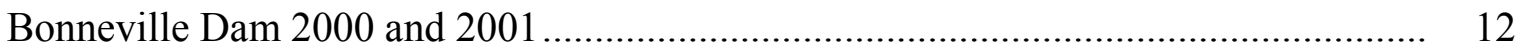

$8 \quad$ River flow at Bonneville Dam near Pierce Island for 2000 and 2001 ...................... 13 


\section{Tables}

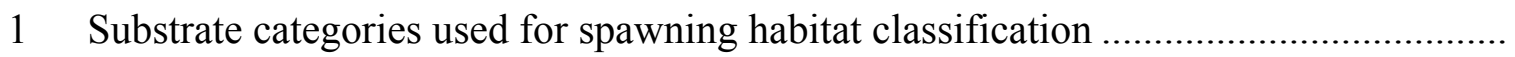

2 Estimated number of fall chinook salmon redds in the primary search zone near Ives and Pierce Island complex from 1999 through 2001 


\section{Introduction}

Pacific Northwest National Laboratory (PNNL) indentified fall chinook salmon (Oncorhynchus tshawytscha) spawning habitat and assessed the extent of spawning in deepwater ( $>1 \mathrm{~m}$ ) downstream of Bonneville Dam in 2001, the third year of such study. Fall chinook salmon have used the Ives and Pierce Island complex located downstream of Bonneville Dam for spawning since 1993 (Hymer 1997). This stock was thought to originate from Bonneville Hatchery. The size of this population was estimated at 1,800 to 5,200 fish from 1994 to 1996 (Hymer 1997), 554 fish in 1998 (Van der Naald et al. 1998-1999), and 704 adult fish in 2000 (Van der Naald et al. 2000-2001). These estimates were based on carcass surveys and visual observation of redds by boat near the shoreline. The Pacific Northwest National Laboratory (PNNL) conducted underwater video surveys from 1999 through 2001 to estimate the number of fall chinook salmon redds occurring in deeper water $(>1 \mathrm{~m}$ ). Estimates of redds were 754 in 1999 (at 143 kcfs), and 787 redds (at $127 \mathrm{kcfs}$ ) in 2000 (Mueller 2001). The majority of the redds found were confined near the main river channel adjacent to Pierce Island.

Chum salmon (O. keta) also utilize the mouth of Hamilton Creek and portions of Hamilton Slough for spawning. The majority of chum salmon were found to spawn in shallow water at the mouth of Hamilton Creek adjacent to Ives Island. Estimates of the natural chum salmon spawning population for 2000 was estimated at 529 (Van der Naald et al. 2000-2001). Chum salmon spawning near Ives Island are part of the Columbia River evolutionary significant unit and included in the Endangered Species Act of 1973 listing in March 1999.

The main objective of this study was to locate deepwater spawning locations of fall chinook salmon in the main Columbia River channel and to collect additional data on physical habitat parameters at spawning sites. The secondary objective was to map any chum salmon redds located near Hamilton Slough. There are several ongoing investigations to define the physical habitat characteristics associated with fall chinook and chum salmon spawning areas near Pierce and Ives Islands (Geist et al. 2001, Van der 
Naald et al. 2000-2001). A major concern is to determine what flows (i.e., surface elevations) are necessary to ensure their long-term survival. This objective is consistent with the high priority that the Northwest Power Planning Council's Independent Advisory Board and the salmon managers have placed on determining the importance of mainstem habitats to the production of salmon in the Columbia River Basin.

\section{Methods}

A primary search zone consisting of regularly spaced transects running perpendicular to the shoreline was established based on previous surveys at Ives and Pierce Islands (Mueller and Dauble 2000; Mueller 2001). Two separate underwater video boat surveys were conducted in late November and early December to document the location and estimated number of fall chinook salmon redds within the search zones. Additional surveys were conducted within the Hamilton Slough area; however, because of low flow conditions, only a limited area was effectively surveyed. The search zones are located approximately $3.5 \mathrm{~km}$ downstream of Bonneville Dam near Columbia River $\mathrm{km} 228.5$ and encompassed known spawning locations of fall chinook salmon (Figure 1). The primary zone $\left(125,000 \mathrm{~m}^{2}\right)$ was segmented into regularly spaced transects, $25 \mathrm{~m}$ apart and $160 \mathrm{~m}$ in length (32 total), running perpendicular to the shoreline. The secondary zone $\left(79,000 \mathrm{~m}^{2}\right)$ was located at the lower end of Pierce Island and consisted of 18 additional transects. Because of flow and environmental conditions, the boat track along each of these transects varied. Each of these zones was surveyed during two separate surveys. A random search zone was used specifically to map any chum salmon redds. The criteria used to classify these redds was be based on smaller area and smaller substrates, or the occurrence of chum carcasses nearby. 


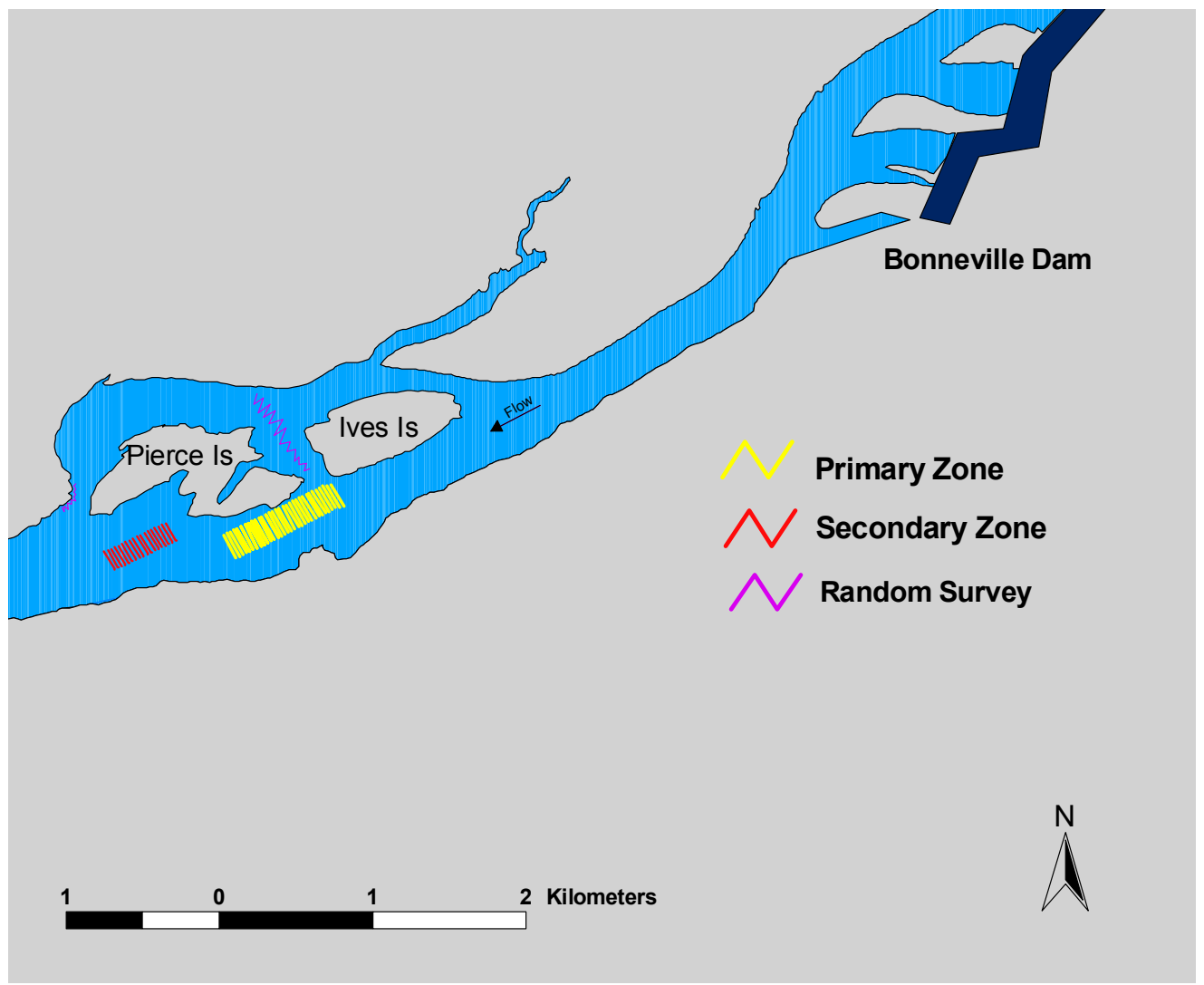

Figure 1. Location of search zones in relation to Ives and Pierce Islands.

A mobile underwater video system was used and consisted of a high-sensitivity remote camera (Sony, model HVM-352) attached to a weighted platform. Recordings were made using a Sony (model GVD 7000) digital 8-mm recorder located on the survey vessel. Two high-resolution monitors were used during the surveys for better viewing of the video obtained by the remote camera. An integrated video/tow cable attached to a manual winch with slip ring mechanisms was utilized to raise and lower the sled to the desired depth. Visual images of redds and bottom substrate were recorded using an underwater video system according to procedures described in Dauble et al. (1999). Changes in background contrast, bed elevation, or substrate composition were the primary criteria used to determine spawning activity. The maximum depth where adequate visual image could be obtained was dependant on water turbidity and ambient light levels. An on-board, real-time differential Global Positioning System (GPS) 
(Trimble Pathfinder ${ }^{\mathrm{TM}}$ Pro XR) was used to collect positional data and to navigate on preset transect grids during the surveys. The integrated GPS beacon receiver and antenna provided GPS corrections for calculating sub-meter accuracy $(\sim 0.5 \mathrm{~m})$. The system's software (ASPEN) displayed a background map of the study site on a personal computer so that researchers could navigate to site locations on a pre-determined transect line and visually verify data accuracy in the field. Both the GPS and video system were synchronized via a time stamp. When a redd was encountered, the time was noted in the logbook as well as a point position with the GPS. Further analysis and verification of redds was performed in the lab. The location of any new redds was also mapped to the geographic information system (GIS).

To determine grain size of the substratum, two underwater lasers C-Map Systems (model HL6312G), pointed downward $18.4 \mathrm{~cm}$ apart, were attached to the underwater platform and provided a reference scale within the camera image. The distance from the camera lens to the substratum ranged from 0.9 to $1.4 \mathrm{~m}$, providing an effective view path of $\sim 2.7 \mathrm{~m}^{2}$ along each transect $(1.5 \mathrm{~m}$ vertical). Grain size was determined by digitizing the image when the camera was positioned near the center portion of the redd and processing the image using a software program $\left(\right.$ Optimas $\left.^{\circledR}\right)$. To remove bias in obtaining measurements, a single rock which was contacted by the right laser beam was measured (long axis diameter). The substrate size for each redd was classified according to five general size categories (Table 1).

Table 1. Substrate categories used for spawning habitat classification (modified from Platts et al. 1983).

\begin{tabular}{||c|l|c||}
\hline Category & Sediment Classification & $\begin{array}{c}\text { Long Axis Diameter of } \\
\text { Individual Substrate }(\mathrm{cm})\end{array}$ \\
\hline \hline 1 & Fines, silt & $<0.61$ \\
\hline 2 & Gravel & $0.6-7.6$ \\
\hline 3 & Medium cobble & $7.6-15.2$ \\
\hline 4 & Large cobble & $15.2-30.5$ \\
\hline 5 & Boulder & $>30.5$ \\
\hline
\end{tabular}


Based on existing literature of fall chinook salmon redd areas, we determined that the minimum average size redd to be approximately $10 \mathrm{~m}^{2}$ (Burner 1951; Chapman et al. 1983; Visser 2000). Based on this value, any redds mapped that fell within a $\sim 1.8 \mathrm{~m}$ radius of a nearby redd were omitted from the overall redd count. This criterion was established to reduce the probability that a redd would be counted more than once for subsequent surveys. In addition, the cumulative number of redds found during both surveys periods was extrapolated to estimate the total number of redds constructed within the primary search zone. These estimates were calculated by taking the total number of redds found during each of the surveys and expanding this number based on the percent coverage (assuming normal distribution) within the total search zone. The total fall chinook salmon redd estimates do not include redds found by other researchers conducting visual redd observations by boat.

Velocity data were collected using a Marsh McBirney (model 2000) flow-meter attached to the camera sled. Measurements were taken at a distance of $\sim 30 \mathrm{~cm}$ above the substratum of 20 randomly selected redds. Turbidity was recorded using a LaMotte (model 2008) turbidimeter. Recorded tapes were reviewed in detail at the PNNL computer lab using a high-resolution monitor. Bathymeteric data was obtained using a one-dimensional, unsteady river flow and water quality computer model MASS1 (Modular Aquatic Simulation System 1D), developed at PNNL. 


\section{Results}

Initial deepwater redd surveys of the main channel near Ives and Pierce Islands were completed on November 29, 2001, after the peak spawning date of November 26 for fall chinook salmon (FPC 2001). Water turbidity was 1.9 nephelometric turbidity units (NTU), and river flows recorded at Bonneville Dam averaged $138 \mathrm{kcfs}$. A total of 28 fall chinook salmon redds were located and mapped within the primary search zone. No redds were found to occur in the secondary search zone. No chum redds were found during this survey.

The second deepwater fall chinook salmon redd survey was completed on December 5 and 6, 2001. Average river flows at Bonneville Dam during the survey period were $\sim 92 \mathrm{kcfs}$ on December 5 (range $90-96 \mathrm{kcfs}$ ) and $\sim 85 \mathrm{kcfs}$ (range $79-88$ kcfs) on December 6. Average turbidity value of 2.1 NTU was slightly higher than the November survey. A total of 43 fall chinook salmon redds were found, all occurring within the primary search area. During a random search to obtain bed velocities at redd sites, we found an additional 21 redds occurring within the primary search zone. These redds were not found during earlier surveys and not included in the extrapolation estimates in Table 2. An additional survey conducted within the Hamilton Slough on December 6 , resulted in the finding of 3 redds. Low water elevation precluded us from surveying the channel between Ives and Pierce Islands where fall chinook redds were known to have occurred during prior year surveys. During both surveys, the depth where visibility was inadequate to observe substrate composition was $\sim 6 \mathrm{~m}$.

The location of all redds found during surveys conducted in 2001 is shown in Figure 2. A listing of all fall chinook salmon redd coordinates found near the main river channel and water depth is in Appendix A. 


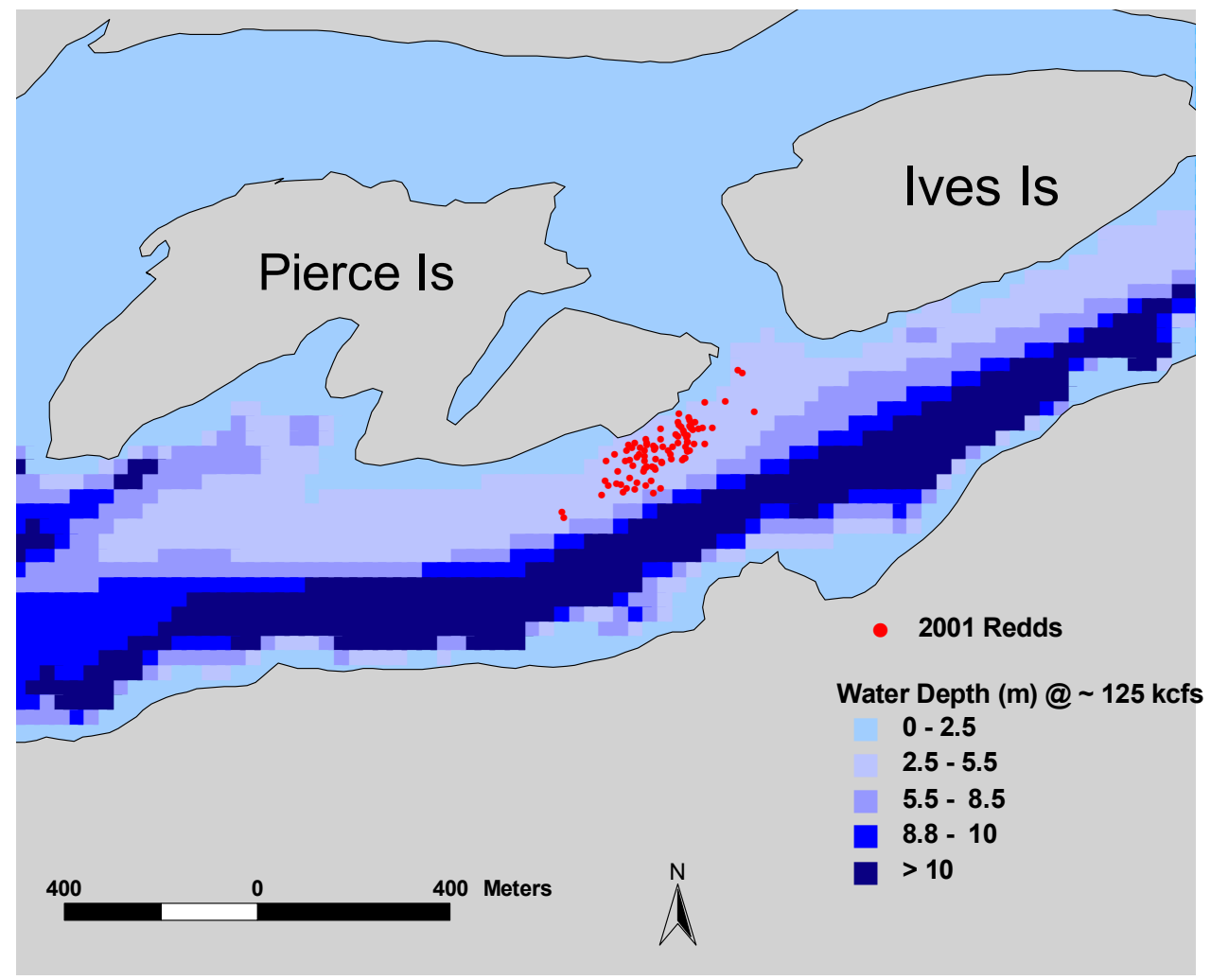

Figure 2. Location of fall chinook salmon redds in the mainstem of the Columbia River below Bonneville Dam in 2001.

Water depths at redd locations ranged from 1.5 to $4.6 \mathrm{~m}$ (Figure 3). Average point velocities were variable and ranged from $0.29-0.7 \mathrm{~m} / \mathrm{s}$. There was no observable correlation between velocity and water depth data obtained during 2000 and 2001 (Figure 4). The dominant substrate size was classified for a subset of the redds found (Figure 5). The dominant grain size in which the redds were constructed consisted of gravel (54\%) and medium cobbles (56\%) (Figure 6).

The areas searched to document any chum salmon redds within Hamilton Slough and at the lower end of Pierce Island were near the locations where Oregon Department of Fish and Wildlife (ODFW) and Washington Department of Fish and Wildlife (WDFW) personnel found redds during shallow water boat surveys. We did not find any redds at the lower end of Pierce Island and found 2 possible chum redds at the upper end 
of Pierce Island at a depth of $1.8 \mathrm{~m}$. The surveys were conducted in the relatively deeper sections of the slough downstream from the mouth of Hamilton Creek where the majority of chum salmon spawning is known to occur. Several salmon carcasses were found during this survey, but they were not identifiable to species.

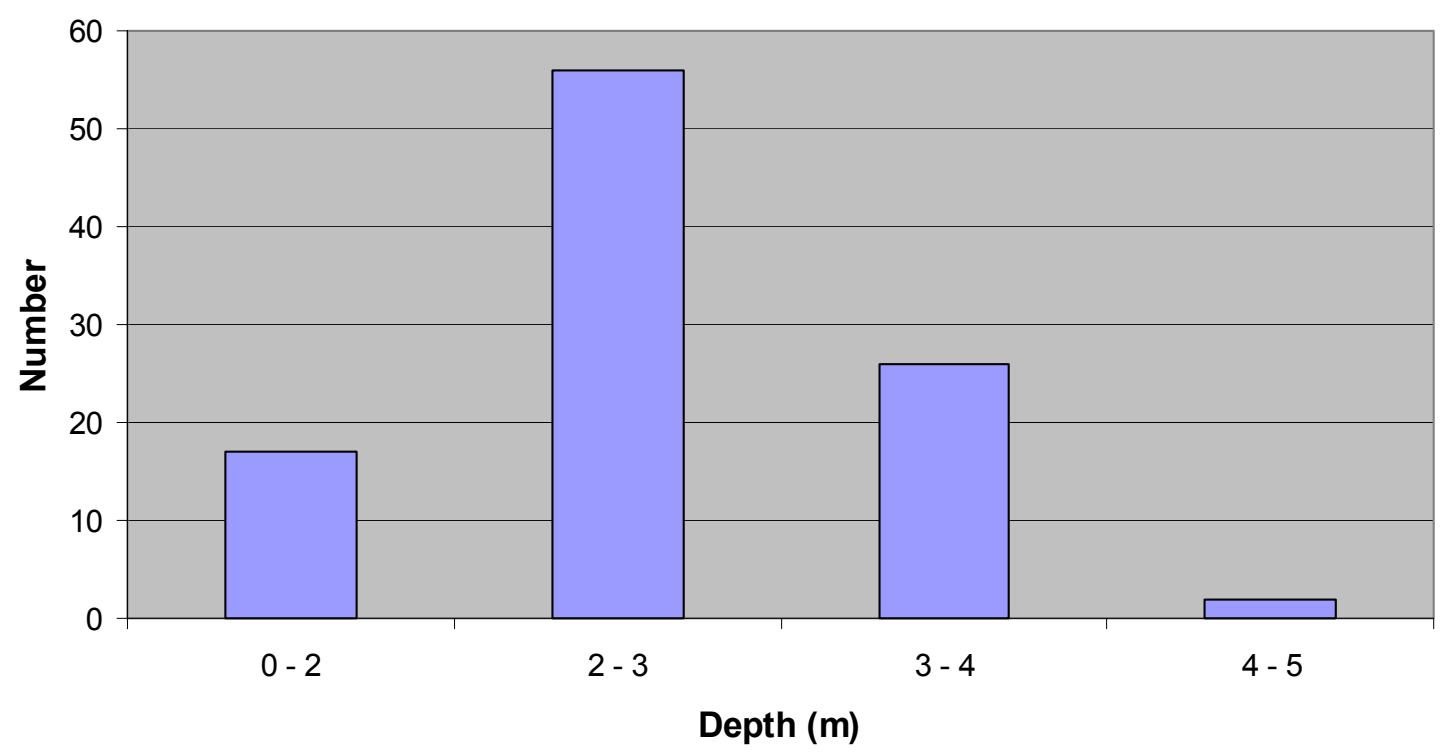

Figure 3. Distribution of fall chinook salmon redds $(n=92)$ relative to water depth found during the November and December 2001 surveys ( $84 \mathrm{kcfs}$ ). 


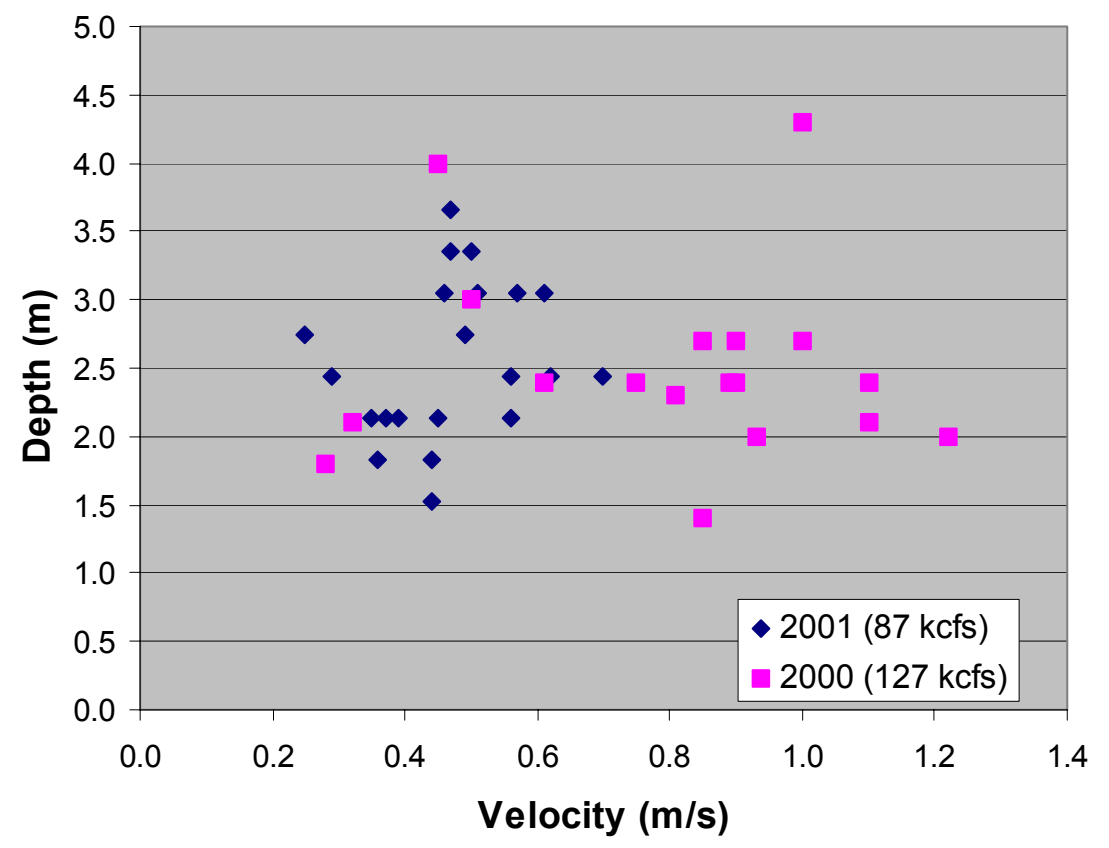

Figure 4. Comparison of water velocities of fall chinook redds relative to water depth for 2000 and 2001.

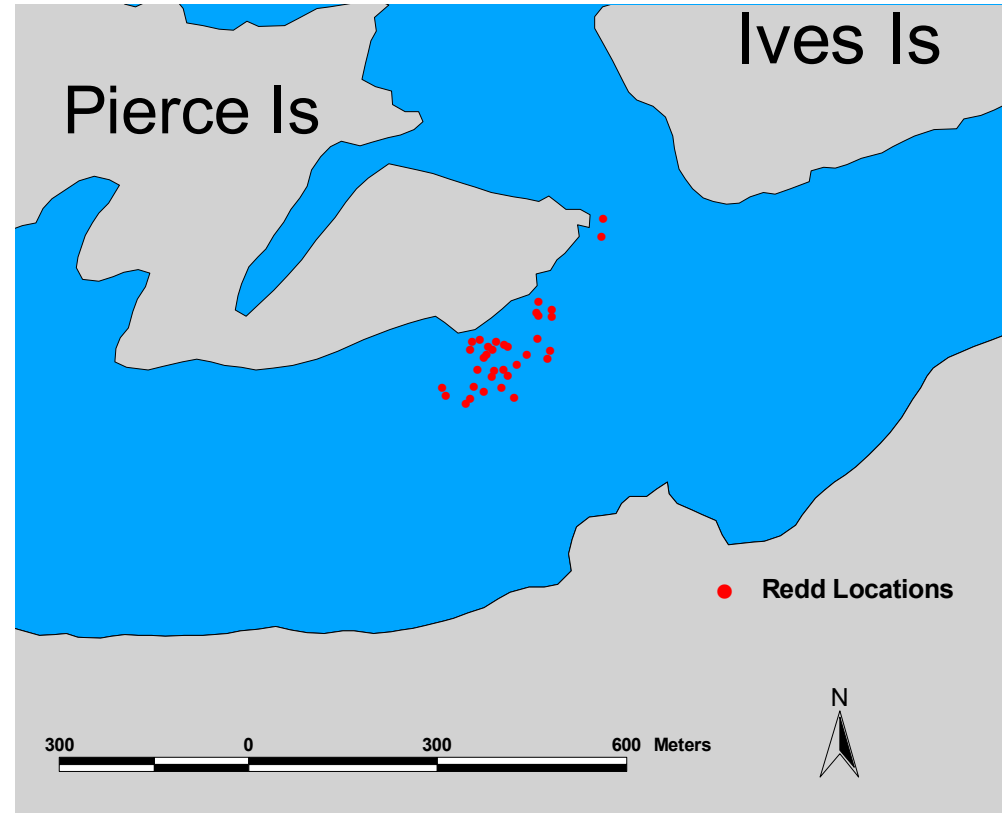

Figure 5. Redd locations where grain size measurements were obtained $(n=35)$. 


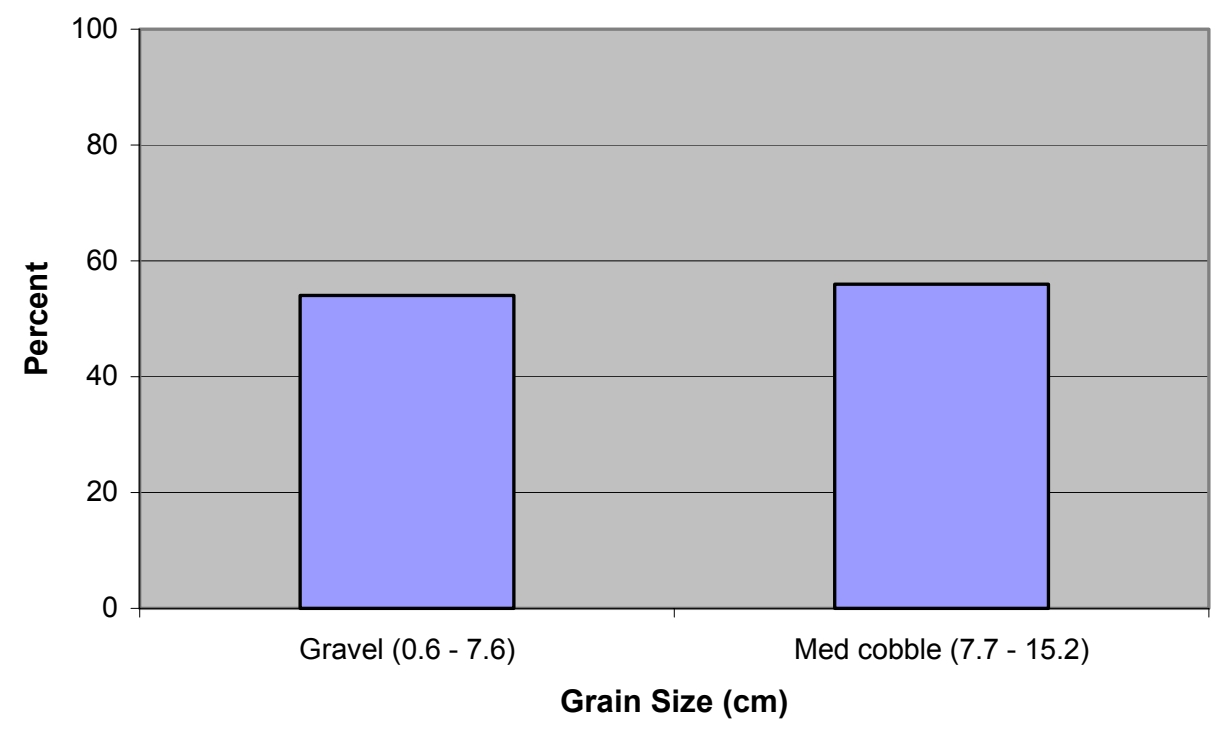

Figure 6. Dominant substrate classification of fall chinook salmon redds $(n=35)$

Based on the actual number of redds found during the highest redd count (December survey) and extrapolating this count based on percent coverage, we estimated $\sim 717$ fall chinook salmon redds were constructed at water depths exceeding $1.5 \mathrm{~m}$ at a river discharge of $\sim 125 \mathrm{kcfs}$ within the primary search zone described earlier (Table 2). Surveys conducted in 1999 and 2000 by PNNL show a similar number of redds (751 and 788 at 143 and $127 \mathrm{kcfs}$ respectively). ODFW and WDFW personnel counted a total of 45 fall chinook salmon redds in the main river channel and 26 redds in the area between Ives and Pierce Islands by wading or observation by boat from November 16 to 28, 2001 (Van der Naald et al. 2000-2001). 
Table 2. Estimated number of fall chinook salmon redds occurring in the primary search zone near Ives and Pierce Island complex from 1999 through 2001.

\begin{tabular}{||l|c|c|c|c|}
\hline Survey Date & $\begin{array}{c}\text { Total Survey } \\
\text { Area in } \\
\text { Primary }\end{array}$ & $\begin{array}{c}\text { \% Video } \\
\text { Coverage } \\
\text { in Primary }\end{array}$ & $\begin{array}{c}\text { Number of } \\
\text { Redds Found }\end{array}$ & $\begin{array}{c}\text { Extrapolated } \\
\text { Redd Estimate }\end{array}$ \\
\hline $\begin{array}{l}\text { November 9-10, } \\
1999\end{array}$ & 109,375 & 9.9 & 36 & 364 \\
\hline December 1-2, 1999 & 109,375 & 8.5 & 64 & 751 \\
\hline $\begin{array}{l}\text { November 8-10, } \\
2000\end{array}$ & 109,375 & 10.6 & 76 & 716 \\
\hline December 5-6, 2000 & 109,375 & 6.5 & 51 & 788 \\
\hline November 29, 2001 & 120,000 & 5.2 & 28 & 538 \\
\hline December 5-6, 2001 & 120,000 & 6.0 & 43 & 717 \\
\hline
\end{tabular}

\section{Summary}

We mapped a total of 92 fall chinook salmon redds near the vicinity of the Pierce Ives island complex downstream of Bonneville Dam in 2001. The majority of the redds were clustered adjacent to Pierce Island similar to the 1999-2000 deepwater surveys. However, the general location shifted downstream and closer to the shoreline (Figure 7). This shift in habitat use was probably related to higher river flows at the beginning of the spawning period in 2000, which were about 20 - $30 \mathrm{kcfs}$ higher than during 2001 (Figure 8).

Fall chinook salmon redds were found down to depths of $4.6 \mathrm{~m}$, bed velocities of $0.29-0.7 \mathrm{~m} / \mathrm{sec}$, and were evenly divided in gravel and cobble substrate. These habitat parameters are within the preferred range of habitat criteria for spawning salmon. The grain size of substrates in which fall chinook salmon spawned during 2001 was generally smaller than those which were measured during 1999 and 2000. The differences in substrate size were probably related to a shift in the general location of the redds to the near shore section adjacent to Pierce Island. Spawning bed velocities recorded during the 
2001 survey were generally lower than those measured at redd locations during 2000 . The lower values can be attributed river flow measured at Bonneville Dam, which was about $40 \mathrm{kcfs}$ lower during the 2001 survey.

River flows during the November survey were moderate at $\sim 125 \mathrm{kcfs}$ and then dropped to near $80 \mathrm{kcfs}$ daily during December 2001. Because of low river flows, any new redds constructed after December 1, were more than likely located near the river channel side of Pierce Island.

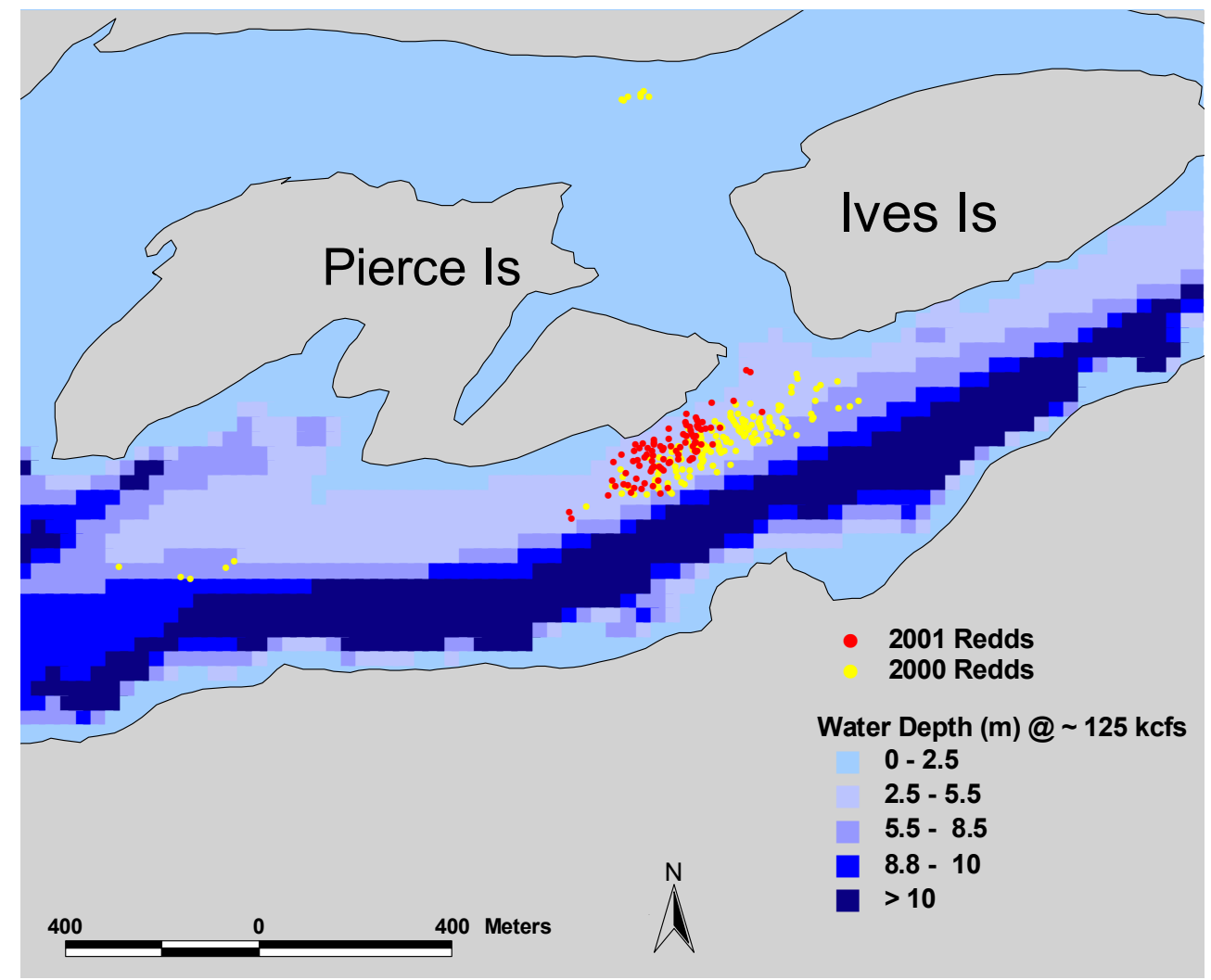

Figure 7. Location of fall chinook salmon redds in the mainstem of the Columbia River below Bonneville Dam for 2000 and 2001. 


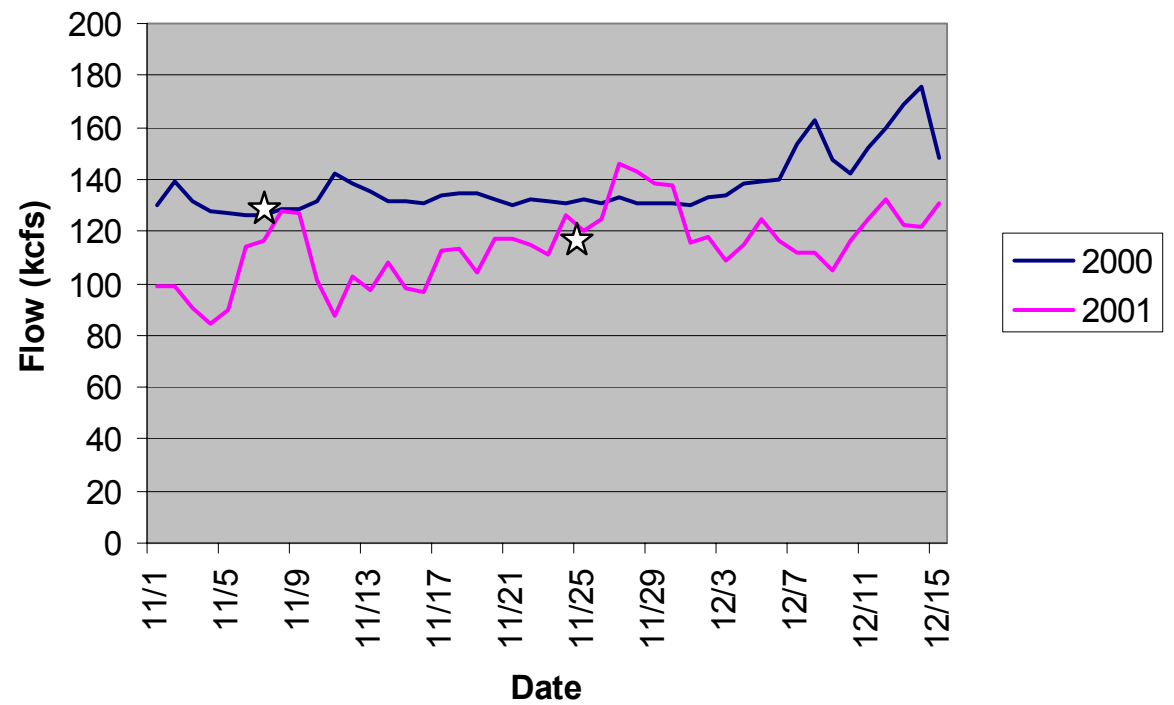

Figure 8. River flow at Bonneville Dam near Pierce Island for 2000 and 2001 (star indicates peak spawning date).

The highest extrapolated redd estimates for the known spawning area during 2001 was 717 redds; this suggest a total spawning population of 2,437 fish using a redd to adult ratio of 3.4 (Visser 2000). This compares to an estimated 2,679 adult fish in 2000 and 2,553 adult fish in 1999, determined by PNNL underwater video surveys. The expansion ratio was established from studies to estimate fall chinook salmon escapement in the Hanford Reach of the Columbia River. These estimates do not include expanded numbers from additional redds found by ODFW and WDFW during boat and wading surveys. The total area utilized by adult fall chinook salmon in 2001 was 4.9 ha; this compares to 6.3 ha in 2000 and 4.0 ha in 1999. The approximate size and location of the spawning area near the river channel has not varied dramatically from 1999 through 2001 (see Appendix B). 


\section{References}

Burner, C.J. 1951. Characteristics of spawning nests of Columbia River salmon. Fishery Bulletin 61, Volume 52. U.S. Fish and Wildlife Service. Washington, D.C.

Chapman, D.W., D.E. Weitkamp, T.L. Welsh, and T.H. Schaldt. 1983. Effects of minimum flow regimes on fall chinook salmon spawning at Vernita Bar 1978-1982. Don Chapman Consultants, McCall, ID, and Parametrix, Inc., Bellevue, WA.

Dauble, D.D., R.P. Mueller, R.L. Johnson, W.V. Mavros, and C.S. Abernethy. 1999. Surveys of fall chinook salmon spawning downstream of Lower Snake River hydroelectric projects. Summary Report for 1993-1998. Prepared for U.S. Army Corps of Engineers, Walla Walla District, Walla Walla, Washington, by Pacific Northwest Laboratory, Richland, WA.

FPC. 2001. Fish Passage Center. http://www.fpc.org/Index.html. 2501 SW First Ave, Suite 230, Portland, OR.

Geist D.R., T.P. Hanrahan, E.V. Arntzen, G.A. McMichael, C.J. Murray, and Y.J. Chien. 2001. Physicochemical characteristics of the hyporheic zone affect redd site selection of chum and fall chinook salmon, Columbia River. Report to Bonneville Power Administration, Contract No. 00000652, Project No. 199300304, 26 electronic pages (BPA Report DOE/BP-00000652-5).

Hymer, J. 1997. Results of studies on chinook spawning in the mainstem Columbia River below Bonneville Dam. Columbia River Progress Report 97-9. Washington Department of Fish and Wildlife, Battle Ground, WA.

Mueller R.P. and D.D. Dauble 2000. Evidence of deepwater spawning of fall chinook salmon spawning near Ives and Pierce Islands of the Columbia River, Annual 1999, Report to Bonneville Power Administration, Contract No. 00000652, Project No. 199900304, 19 electronic pages (BPA Report DOE/BP-00000652-2).

Mueller R.P. 2001. Deepwater spawning of fall chinook salmon near Ives and Pierce Island of the Columbia River. Annual 2000, Report to Bonneville Power Administration, Contract No. 00000652, Project No. 199300304, 27 electronic pages (BPA Report DOE/BP-00000652-6).

Platts, W.S., W.F. Megahan, and G.W. Minshall. 1983. Methods for evaluating stream, riparian, and biotic conditions. U.S. Forest Service Technical report INT-138, U.S. Forest Service, Washington D.C. 
Van der Naald, W., B. Spellman, and R. Clark. 1998-1999. Evaluation of fall chinook and chum salmon spawning below Bonneville, The Dalles, and McNary Dams, Oregon Department of Fish and Wildlife, Report to Bonneville Power Administration, Contract No. 1999BII5007, Project No. 199900302, 43 electronic pages (BPA Report DOE/BP-15007-1).

Van der Naald, W., B. Spellman, and R. Clark. 2000-2001. Evaluation of fall chinook and chum salmon spawning below Bonneville, The Dalles, and McNary Dams, Oregon Department of Fish and Wildlife, Report to Bonneville Power Administration, Contract No. 00004028, Project No. 199900301, 33 electronic pages (BPA Report DOE/BP00004028-1).

Visser, R.H. 2000. Utilizing remotely sensed imagery and GIS to monitor and research salmon spawning: A case study of the Hanford Reach fall chinook (Oncorhynchus tshawytscha), Prepared for the US DOE by the Pacific Northwest National Laboratory PNNL-13177. 


\section{Appendix A}

PNNL Redd Coordinate Description

\begin{tabular}{||l|l||}
\hline \multicolumn{1}{|c|}{ Projection } & \multicolumn{1}{c|}{ Stateplane } \\
\hline \hline Zone & WA South 4602 \\
\hline Datum & NAD83 \\
\hline Units & Meters \\
\hline Vertical Datum & NGVD29 \\
\hline
\end{tabular}

\begin{tabular}{||c|c|c|c||}
\hline \hline & Northing & Easting & Depth $(\mathrm{m})$ \\
\hline \hline 1 & 33026.925 & 383149.845 & 1.2 \\
\hline 2 & 33032.682 & 383141.750 & 1.2 \\
\hline 3 & 32968.371 & 383115.075 & 2.1 \\
\hline 4 & 32965.329 & 383071.436 & 1.5 \\
\hline 5 & 32908.739 & 383048.627 & 2.4 \\
\hline 6 & 32924.198 & 383051.099 & 2.4 \\
\hline 7 & 32934.377 & 383039.169 & 2.4 \\
\hline 8 & 32915.330 & 383024.266 & 2.4 \\
\hline 9 & 32893.072 & 383033.835 & 2.4 \\
\hline 10 & 32882.959 & 383036.930 & 2.7 \\
\hline 11 & 32866.140 & 383035.621 & 3.0 \\
\hline 12 & 32873.453 & 383031.056 & 3.0 \\
\hline 13 & 32877.971 & 383049.185 & 3.4 \\
\hline 14 & 32849.814 & 383028.903 & 3.7 \\
\hline 15 & 32899.883 & 383011.756 & 2.1 \\
\hline 16 & 32873.395 & 382986.226 & 2.4 \\
\hline 17 & 32864.965 & 382996.373 & 2.4 \\
\hline 18 & 32847.292 & 383002.407 & 2.7 \\
\hline 19 & 32867.549 & 382967.859 & 2.4 \\
\hline 20 & 32869.935 & 382921.019 & 1.5 \\
\hline 21 & 32855.392 & 382948.563 & 1.5 \\
\hline 22 & 32844.193 & 382947.151 & 2.1 \\
\hline 23 & 32832.713 & 382951.633 & 2.7 \\
\hline 24 & 32791.780 & 382949.994 & 3.7 \\
\hline 25 & 32786.003 & 382926.561 & 3.4 \\
\hline 26 & 32794.470 & 382898.305 & 3.0 \\
\hline 27 & 32738.675 & 382775.835 & 2.7 \\
\hline 28 & 32724.616 & 382780.965 & 3.0 \\
\hline 29 & 32946.613 & 383175.194 & 2.4 \\
\hline \hline & & & \\
\hline
\end{tabular}

A. 1 


\begin{tabular}{|c|c|c|c|}
\hline & Northing & Easting & Depth (m) \\
\hline 30 & "32913.278 & 383088.485 & 3.0 \\
\hline 31 & 32879.411 & 383073.059 & 3.7 \\
\hline 32 & 32912.688 & 383067.971 & 3.0 \\
\hline 33 & 32910.010 & 383057.923 & 2.4 \\
\hline 34 & 32916.578 & 383040.123 & 2.1 \\
\hline 35 & 32929.105 & 383040.232 & 1.5 \\
\hline 36 & 32941.281 & 383019.192 & 1.5 \\
\hline 37 & 32923.595 & 383016.150 & 1.8 \\
\hline 38 & 32918.655 & 383018.342 & 1.8 \\
\hline 39 & 32850.982 & 383032.423 & 3.7 \\
\hline 40 & 32863.470 & 383037.112 & 3.7 \\
\hline 41 & 32881.782 & 383017.301 & 2.4 \\
\hline 42 & 32895.045 & 383017.601 & 2.1 \\
\hline 43 & 32911.161 & 382981.982 & 1.5 \\
\hline 44 & 32856.205 & 383000.485 & 2.7 \\
\hline 45 & 32841.636 & 382983.850 & 3.0 \\
\hline 46 & 32869.547 & 382970.639 & 2.1 \\
\hline 47 & 32873.483 & 382965.064 & 2.1 \\
\hline 48 & 32877.688 & 382952.388 & 1.8 \\
\hline 49 & 32881.625 & 382926.710 & 1.8 \\
\hline 50 & 32869.383 & 382939.419 & 1.8 \\
\hline 51 & 32864.861 & 382946.479 & 2.1 \\
\hline 52 & 32832.403 & 382962.826 & 3.0 \\
\hline 53 & 32824.476 & 382970.441 & 3.0 \\
\hline 54 & 32787.591 & 382980.255 & 4.6 \\
\hline 55 & 32776.248 & 382964.871 & 4.6 \\
\hline 56 & 32822.192 & 382944.831 & 2.7 \\
\hline 57 & 32852.961 & 382931.768 & 2.1 \\
\hline 58 & 32877.841 & 382913.376 & 1.8 \\
\hline 59 & 32855.975 & 382935.797 & 2.4 \\
\hline 60 & 32830.706 & 382949.349 & 3.0 \\
\hline 61 & 32803.650 & 382960.846 & 3.7 \\
\hline 62 & 32834.446 & 382921.960 & 2.4 \\
\hline 63 & 32846.179 & 382916.614 & 2.4 \\
\hline 71 & 32772.996 & 382857.309 & 3.0 \\
\hline 72 & 32842.755 & 382866.582 & 2.4 \\
\hline 73 & 32796.769 & 382889.708 & 2.7 \\
\hline 74 & 32820.403 & 382892.343 & 2.4 \\
\hline 75 & 32856.804 & 382884.510 & 1.5 \\
\hline 71 & 32772.996 & 382857.309 & 3.0 \\
\hline 76 & 32843.915 & 382907.799 & 2.4 \\
\hline 77 & 32828.298 & 382947.632 & 2.7 \\
\hline 78 & 32886.925 & 382950.698 & 1.8 \\
\hline 79 & 32838.665 & 382982.294 & 3.0 \\
\hline 80 & 32829.561 & 382966.912 & 3.4 \\
\hline
\end{tabular}

A. 2 


\begin{tabular}{||l|c|c|c||}
\hline \hline & Northing & Easting & Depth $(\mathrm{m})$ \\
\hline \hline 81 & 32847.952 & 382970.822 & 3.0 \\
\hline 82 & 32882.256 & 382952.069 & 2.1 \\
\hline 83 & 32888.840 & 382981.777 & 2.1 \\
\hline 84 & 32871.446 & 383004.662 & 2.4 \\
\hline 85 & 32846.084 & 383025.028 & 3.7 \\
\hline 86 & 32864.863 & 383040.811 & 3.4 \\
\hline 87 & 32882.748 & 383037.112 & 3.0 \\
\hline 88 & 32900.557 & 383028.917 & 3.0 \\
\hline 89 & 32906.870 & 383028.399 & 2.1 \\
\hline 90 & 32919.120 & 383042.627 & 1.8 \\
\hline 91 & 32896.572 & 383037.259 & 2.1 \\
\hline 92 & 32913.327 & 383042.625 & 2.1 \\
\hline \hline
\end{tabular}

A. 3 


\section{Appendix B}

Maps Illustrating Fall Chinook Salmon Redd Spawning Areas 1999-2001
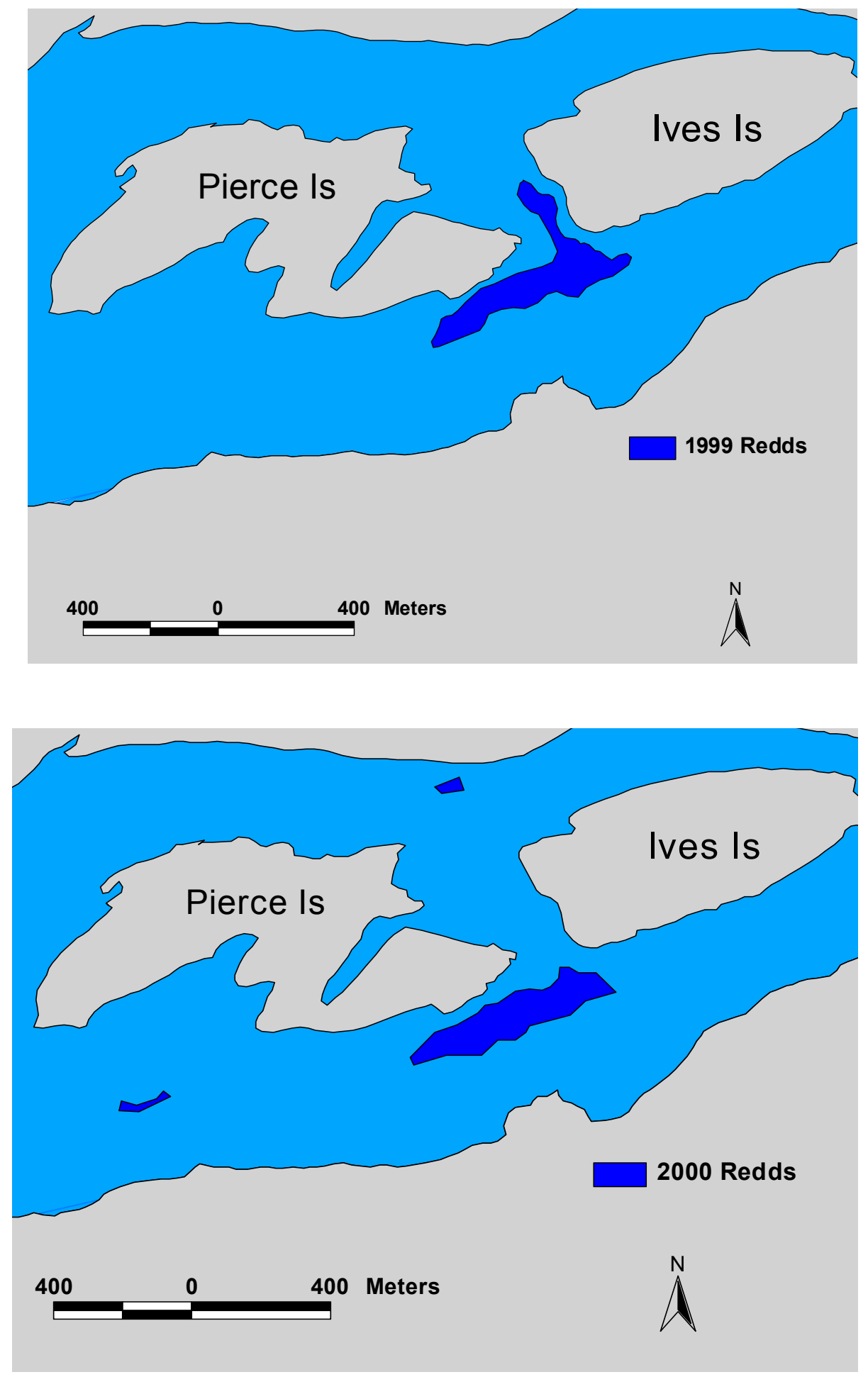

B. 1 


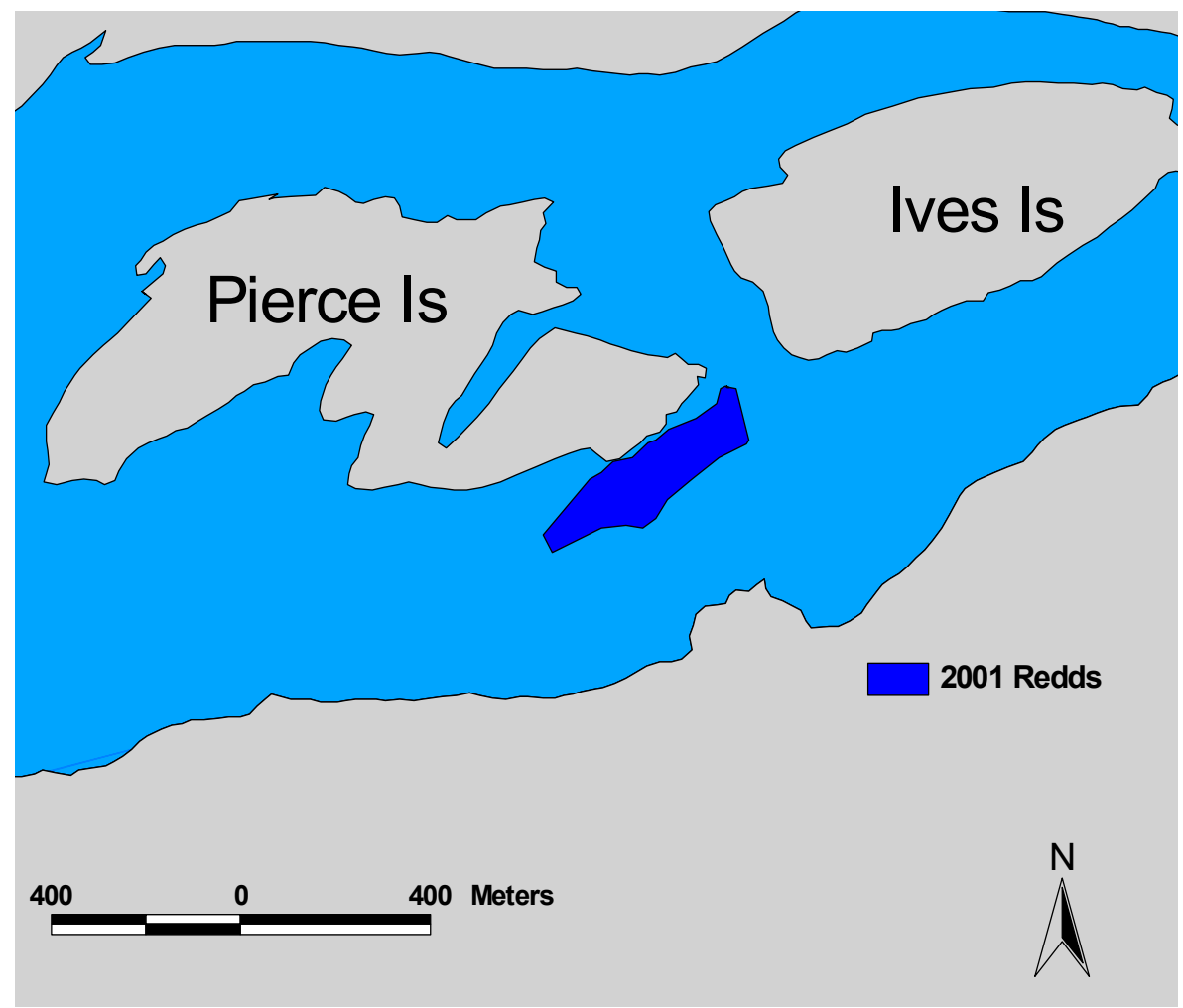

B. 2 